\title{
Nuclear Warehouse: Emphasize on Energy Efficiency Strategy in Global Supply Chain
}

\author{
Jaka Aminata*, Samuel Grandval**, Abdelkader Sbihi ${ }^{* * *}$
}

\begin{abstract}
The aim of this study is to provide energy supply chain in Indonesia. Therefore, the best scenario has been created to fulfill energy scarcity by global supply chain partnership. All impact social-economy will be advantages. The input output analysis has been applied in this paper. The impact of output and impact of job creation are possible to describe, significantly. All barriers and opportunities that can be achieve from the lowest price, efficiency and also to reduce unemployment rate during a decade of building nuclear power plants. This research work can be applicable model for future nuclear power plants construction or other type of energy source construction that give significant impact to the economy and business sustainability. Therefore, by this project plan will cover energy needs for domestics and improve the local corporate productivity, especially for nuclear power plants equipment.
\end{abstract}

Key words : Input-Output Analysis, Electricity, Global, Supply Chain, Transmission, Efficiency

JEL classification : $C 6 \& Q 48$

\footnotetext{
${ }^{*}$ University of Le Havre - NIMEC \& École de Management de Normandie (EMN) jaka.aminata@doct.univ-lehavre.fr

** samuel.grandval@univ-lehavre.fr

***a.sbihi@em-normandie.fr
} 


\section{Introduction1)}

The location of project planning is in Muria peninsula, $25,000 \mathrm{~m} 2$. The power plants construction is needed due to the massive energy demand. The nuclear power plant will contribute to national demand $4 \%$. The estimation for 2015 confirmed that the national demand for electricity 100 Gigawatt. However, in this decade is available 34 Gigawatt, only. All need in this research work is about management skill; particularly on energy management logistics and supply chain management inter island. This study is to measure the impact of nuclear power plant and its significances to global supply chain that will occur to this site plant. The economic activity will increase if the site plant construction well executed. The study can be explored for prep-construction and phase of construction. By certain condition this study estimated the impact of site plants construction in specific scale of regional level. The necessary of theoretical background and literature review will contribute in this research. Moreover, to understand well the mechanism of nuclear plants site. The issue of oversupply electricity is the next step of current contemporary issue in France and Germany regarding to the safety for running nuclear power plants from natural disaster.

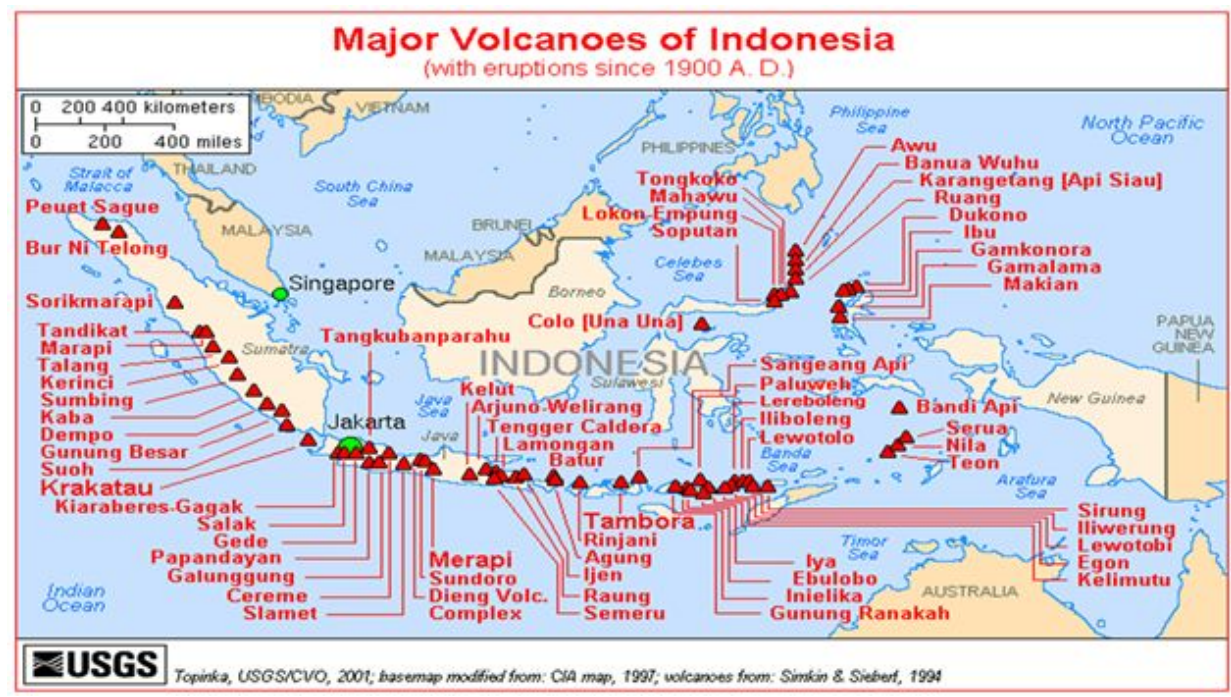

Source: USGS, 2012

\section{Figure 1.}

Indonesia's Volcanoes

1) Thank you for KHNP-Korea, FEB UGM-IDN, and FEB UNDIP-IDN for data shared and also as a team member, particularly field work investigation at local region level and national level. 
Nuclear power plants need enormous of uranium stock. Fortunately, a huge amount of uranium exists in Kalimantan Indonesia. The local administrative is waiting for central government to build up nuclear power plants. Enormous amount of uranium closed to 900 tons, precisely at Melawi regency, west Kalimantan. The current of Indonesia's uranium reserve of at least 53,000 tons which might be used enough for basic material to build nuclear power plants. It's included 29,000 tons in Bangka Belitung. Approximately 1,000 MW, Nuclear power plants needs 200 tons uranium per year. By reaching 29,000 tons the plants can be operated for 145 years. For Papua island needs some field work-research, stated by Development of Cycle Technology of Nuclear Substance and Engineering of the National Nuclear Energy Agency (BATAN-Indonesia). However, Economic development is the process of the local government and community to manage all resources to create economic growth and local economic activities. The endogenous development, institutional developments are important to support local government activities.

\section{Table 1.}

Nuclear Power Plants World-Wide

\begin{tabular}{|c|c|c|c|c|}
\hline \multirow{3}{*}{ Country } & \multicolumn{2}{|c|}{ In operation } & \multicolumn{2}{|c|}{ Under construction } \\
\hline & \multirow[t]{2}{*}{ Number } & $\begin{array}{l}\text { Electr. net } \\
\text { output }\end{array}$ & \multirow[t]{2}{*}{ Number } & $\begin{array}{l}\text { Electr. net } \\
\text { output }\end{array}$ \\
\hline & & Mw & & Mw \\
\hline Argentina & 2 & 935 & 2 & 717 \\
\hline Armenia & 1 & 375 & - & \\
\hline Belarus & - & - & 1 & 1.109 \\
\hline Belgium & 7 & 5,927 & - & \\
\hline Brazil & 2 & $1, \mathrm{SS4}$ & 1 & 1,245 \\
\hline Bulgaria & 2 & 1,906 & - & \\
\hline Canada & 19 & 13,5 & - & \\
\hline China & & & & \\
\hline (6 reactors in $T$ aiwan) & 21 & 16,89 & $2 \mathrm{~s}$ & 27,756 \\
\hline Czech Republic & 6 & 3,804 & - & \\
\hline Finland & 4 & 2,752 & 1 & 1,6 \\
\hline France & 58 & 63,13 & 1 & 1,6 \\
\hline Germany & 9 & 12,068 & - & 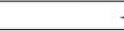 \\
\hline Hungary & 4 & 1,389 & - & \\
\hline India & 21 & 5,305 & 6 & 3,907 \\
\hline Iran & 1 & 915 & - & \\
\hline Japan & 48 & $42,3 \mathrm{ss}$ & 2 & 1.325 \\
\hline Korea, Republic & 23 & 20,71 & 5 & 6,37 \\
\hline Mexico & 2 & 1,33 & - & -1 \\
\hline Netherlands & 1 & 482 & - & 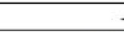 \\
\hline Pakistan & 3 & 690 & 2 & 630 \\
\hline Romania & 2 & 1,3 & - & 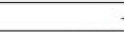 \\
\hline Russian Federation & 33 & 23,643 & 10 & 5,352 \\
\hline Slovalian Republic & 4 & $1, \mathbf{S 1 5}$ & 2 & ssc \\
\hline Slovenia & 1 & $68 s$ & - & -1 \\
\hline Sout th Africa & 2 & 1,86 & - & -1 \\
\hline Spain & 7 & 7,121 & - & -1 \\
\hline Sweden & 10 & 9,474 & - & 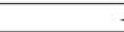 \\
\hline Switzerland & 5 & 3,305 & - & 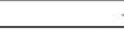 \\
\hline Ulkraine & 15 & 13,107 & 2 & 1,9 \\
\hline United Arab Emirates & - & & 2 & 2,69 \\
\hline United Kingd om & 16 & 9,231 & - & \\
\hline USA & 104 & 101,465 & 5 & 5,633 \\
\hline Total & 435 & 372,022 & 72 & 68,34 \\
\hline
\end{tabular}




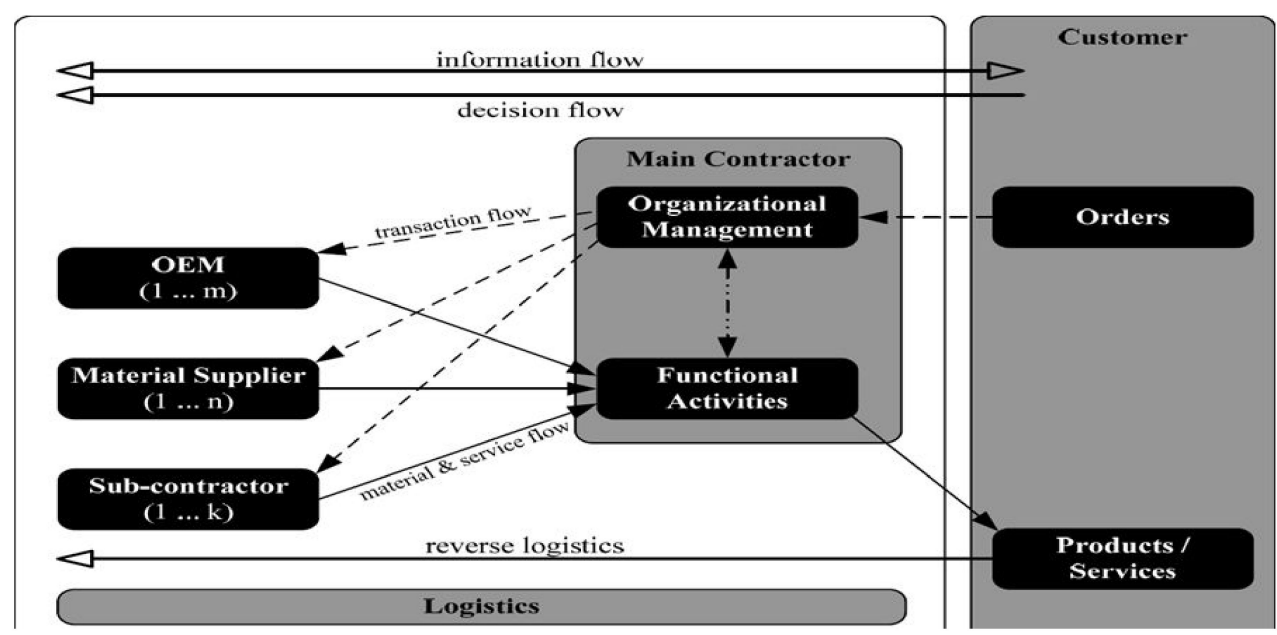

Andrej Androjna1, Robert Bizjak, Bojan Rosi2; Logistics \& Sustainable Transport, Volume: 1, Issue: 4

\section{Figure 2.}

\section{A Specific Maintenance Supply Chain Model}

Supply chain management is well-known concept in logistics. Cooper and Ellram (1993) SCM is: "an integrative philosophy to manage the total flow of a distribution channel from the supplier to the ultimate user". Mentzer et all. (2001) define a supply chain as: "A set of three or more entities directly involved in the upstream and downstream flows of products, services, finances, and/or information from a source to a customer. Cooper et all (1997): "The integration of business processes from end user through original suppliers that provides products, services and information that add value for customers." Mouritsen, 2003, "there is an emphasis on flows of products, services and information between firms, which have to be organized and managed as if they belong to one entity".

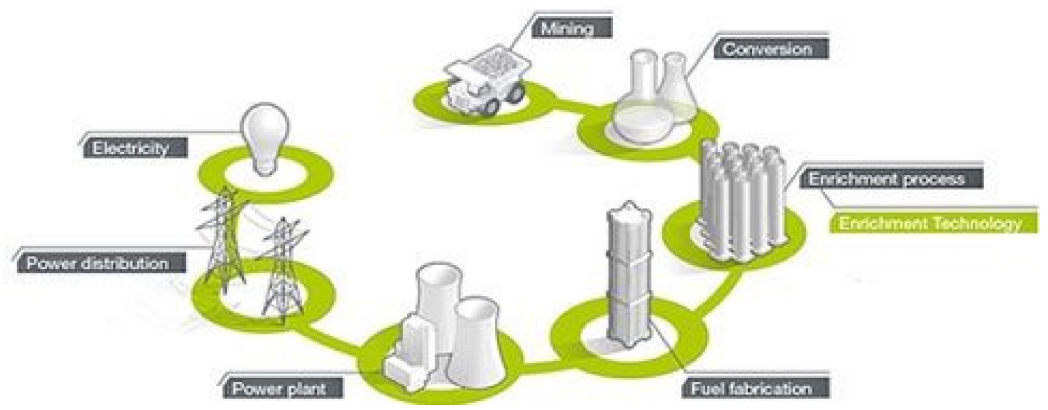

Figure 3.

The Flows of Uranium Mining to Electric Production 


\section{Theoretical Reviews}

Energy Global Supply Chain, Four Pillars of Support for a Fast-Globalizing Nuclear Industry:

See, IAEA, (1975), Sulfikar, (2010), Yount (2005) and Berkeley \& Wallace, (2010)

a. The nuclear industry's regulatory and policy environment

b. Engage efficiently in nuclear commerce, a global industry now representing nearly 15,000 reactor-years.

c. International supply chains for reactor new-build and ongoing nuclear operations

d. Comprehensive presentation of the facts on nuclear energy worldwide (public education).

A threefold categorization of the competencies necessary to run a nuclear power plant can be drawn, which includes, see IAEA (2013):

1) "Nuclear" people with a specialized formal education in nuclear subjects (e.g. nuclear engineering, radio-chemistry, radiological protection, etc.)

2) "Nuclearized" people with formal education and training in a relevant (non-nuclear) area (e.g. mechanical, electrical, civil engineering, systems) but who need to acquire knowledge of the nuclear environment in which they have to apply their competencies;

3) "Nuclear-aware" people requiring nuclear awareness to work in the industry (e.g. Electricians, mechanics, and other crafts and support personnel). 


\section{Table 2.}

Typical of Power and Equipment

\begin{tabular}{|c|c|}
\hline Sector & $\begin{array}{l}\text { Typical Equipment and Service } \\
\text { Requirements }\end{array}$ \\
\hline $\begin{array}{l}\text { Power generation reform and new build } \\
\text { and power networks }\end{array}$ & $\begin{array}{l}\text { - Boilers } \\
\text { - Soot blowers } \\
\text { - Burners } \\
\text { - Waste handling } \\
\text { - Large pumps and compressors } \\
\text { - Pipework and pressure vessel fabrication } \\
\text { - Pollution control and monitoring } \\
\text { - Process design and engineering services } \\
\text { - Plant construction and fabrication } \\
\text { - Project management services }\end{array}$ \\
\hline Transmission power networks & $\begin{array}{l}\text { - Switch gear } \\
\text { - Substations } \\
\text { - Cables } \\
\text { - Connectors } \\
\text { - Pylon fabrication and Installation } \\
\text { - Heavy duty fuse boxes }\end{array}$ \\
\hline Smart & $\begin{array}{l}\text { - Sensors } \\
\text { - Electronic Control Systems } \\
\text { - ICT equipment and services } \\
\text { - Smart Meters } \\
\text { - Installation services } \\
\text { - Power inverters } \\
\text { - Grind scale and small scale energy storage } \\
\text { systems }\end{array}$ \\
\hline
\end{tabular}

Source: Nuclear Development, 2012

\section{Economic Base Theory}

The economic base theory stated that the main factor for economic growth correlated to supply and demand for goods and services from out of region or border. The industrial growth use local resource for example labor, raw materials and job creation.

\section{Location Theory}

The location theory explained how to expand the industrial location. The corporate tend to minimize all cost by choose the best location and get closer to the market. In the reality, industrial development is trying to get lower cost between production factor (wages, energy cost, supply chain product end service, and communication) in the market. The corporate with difference of type needs trying to fix all production factors, especially to get lowest price. The limitation is technology level. By modern communication, it will increase the contribution level for production activity and distribution management. Principally, all 
kind of business activities are based on where they can get the profit higher than other place. Seemingly, the household looking for the suitable place based on the level of opportunity to get a job.

\section{I-O Projection and Input Output Model}

To study interconnection or link between production sectors in economy, the best model or methodology is input-output model. The first input-output model developed by Wassily Leontief from Harvard University in 1930s. The input output model is one of the powerful models to see the interaction between economic sectors. The economic structure can be found easily in input output model. The economy structure consists of a country, region, and metropolitan and inter region. The input output analysis is the tool to know the general equilibrium. The equilibrium in input output analysis based on transaction in economy. The critical point in this methodology is production side, level of technology that must be used in intermediate input.

\section{Leontief Production Function}

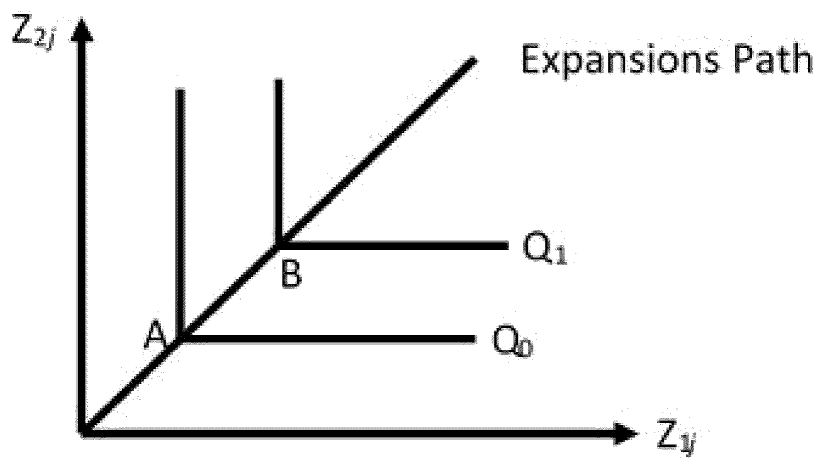

Source: Miller and Blair (1985)

Figure 4.

Isoquant Leontief Production Function

Alongside isoquant of a production process, there is only one optimal point of production as seen in the image above that point $\mathrm{A}$ to point B and $Q_{0}$ isoquant to isoquant 
$Q_{1}$. The Leontief production function has constant returns to scale production. All input folded-time, then the output will also be multiplied by the lambda-time. This applies to the order to each sector in the economy.

\section{The Output Distribution and Input Production}

The output produced by sector, sector $i$ is distributed to the two users. First, users who use the output for further production process, and second, users who use the output for final use. The first user is the production sector, while the second user is the end user. For the first user, the output of sector $i$ are the raw materials or intermediate inputs (intermediate inputs), while for the second user, the output sector $i$ is final demand. In the context of intermediate inputs, movements of goods between sectors, from sector $i$ to sector $j$. From sector $i$ to sector $i$ itself, or so called displacement intra sector. In other words, the displacement of sector $i$ to sector $j$, where $i=j$. The value of the money flow of goods from sector $i$ to sector $j$ given notation $z_{i j}$, the total output of sector $i$ given the notation $X_{i}$ and the total final demand sector $i$ is given the notation $Y_{i}$. Thus can be written that:

$$
X_{i}=Z_{i 1}+Z_{i 2}+\cdots+Z_{i n}+Y_{i}
$$

In equation above shows, that there are $\mathrm{n}$ sectors in the economy. Thus, there will be $\mathrm{n}$ equations for the whole economy, namely:

$$
\begin{aligned}
& X_{i}=Z_{i 1}+Z_{i 2}+\cdots+Z_{i n}+Y_{i} \\
& X_{2}=Z_{21}+Z_{22}+\cdots+Z_{2 n}+Y_{2} \\
& X_{3}=Z_{n 1}+Z_{n 2}+\cdots+Z_{n m}+Y_{n}
\end{aligned}
$$

For each column, note that can be written a column vector containing:

$$
\left[\begin{array}{c}
Z 11 \\
Z 12 \\
Z 13 \\
\vdots \\
Z n 1
\end{array}\right]
$$

Coefficient reflects the amount of inputs required by one sector from the sector 1's. Similarly, $Z_{21}$ is the number of inputs from sector 1 sector 2 . That way, the vector field 
above another does not show the structure of the input sector 1 . The vectors show the magnitude of the input sector 1 of the other production sectors, and also from sector 1 itself. Input is called the intermediate input.

However, the inputs required in the production process of the sector i not only between the inputs. Production sector also requires other inputs are often called primary inputs. None other than the primary input factors of production factors of production such as labor, capital, land, and so on. With the use of production factors such as input, then no remuneration of production factors in the production process. For example, the remuneration of production factors labor is the wage or salary, remuneration of production factors are capital leases or capital interest, remuneration of factors of production land is lease land, and so on. Remuneration of the factors of production is called the value added of the production process.

The factors of production in the economy are not all used up in the production sectors. There are also the factors of production are used as final demand. In addition of intermediate inputs purchased from other sectors in the economy, and the primary input in the form of the factors of production, the production process of certain sectors can also buy inputs from abroad, in the form of imports.

Table 3.

Transaction of Input Output Table

\begin{tabular}{|c|c|c|c|c|c|c|c|c|c|}
\hline & & & \multirow{2}{*}{\multicolumn{2}{|c|}{$\begin{array}{c}\text { Intermediate demand } \\
\text { Production sector }\end{array}$}} & \multirow{2}{*}{\multicolumn{4}{|c|}{ Final demand }} & \multirow{3}{*}{\begin{tabular}{|l|} 
Total \\
Output \\
$X$ \\
\end{tabular}} \\
\hline & & & & & & & & & \\
\hline & & & 1 & 2 & C & $\mathrm{I}$ & G & $\mathrm{E}$ & \\
\hline \multirow{2}{*}{$\begin{array}{l}\text { Intermediate } \\
\text { Input }\end{array}$} & \multirow{2}{*}{$\begin{array}{l}\text { Production } \\
\text { sector }\end{array}$} & 1 & Z11 & Z12 & $\mathrm{C} 1$ & I1 & G1 & E1 & $\mathrm{X} 1$ \\
\hline & & 2 & $\mathrm{Z} 21$ & $\mathrm{Z} 22$ & $\mathrm{C} 2$ & I2 & G2 & E2 & $\mathrm{X} 2$ \\
\hline \multirow{2}{*}{\multicolumn{2}{|c|}{ Value added }} & $\mathrm{L}$ & L1 & L2 & $\mathrm{LC}$ & LI & LG & LE & $\mathrm{L}$ \\
\hline & & $\mathrm{N}$ & N1 & N2 & $\mathrm{NC}$ & $\mathrm{NI}$ & NG & $\mathrm{NE}$ & $\mathrm{N}$ \\
\hline \multicolumn{2}{|l|}{ Import } & $\mathrm{M}$ & M1 & M2 & MC & MI & MG & ME & $\mathrm{M}$ \\
\hline \multicolumn{2}{|l|}{ Total Input } & $x$ & $\mathrm{X} 1$ & $\mathrm{X} 2$ & C & $\mathrm{I}$ & $G$ & $\mathrm{E}$ & $X$ \\
\hline
\end{tabular}

The table above is often referred as the input-output transactions table. It is assumed in the economy there are only two production sectors (sector 1 and sector 2); there are four components of final demand, household consumption (C), investment firms (I), government spending $(\mathrm{G})$, and foreign exports (E); two factors of production, namely labor wage remuneration $(\mathrm{L})$ and capital $(\mathrm{N})$. In addition, the production sectors and end users can also buy goods from abroad in the form of imports (M).

Matrix with elements in the upper-left group called the input matrix. So it can be made between the input matrixes, $Z$, which read: 


$$
Z=\left[\begin{array}{l}
Z_{11} Z_{12} \\
Z_{21} Z_{22}
\end{array}\right]
$$

So it can be made a primary input matrix, $\mathrm{W}$, which read:

$$
Z=\left[\begin{array}{l}
Z_{11} Z_{12} \\
Z_{21} Z_{22}
\end{array}\right]
$$

While the matrix with elements in the upper-right group called the matrix of final demand. The contents of this matrix are the final demand for each sector in the economy. In the discussion, the matrix is usually used as a column vector, which each element is the total final demand of each sector in the economy.

The final demand matrix form is:

$$
\begin{aligned}
& Y=\left[\begin{array}{llll}
C_{1} & I_{1} & G_{1} & E_{1} \\
C_{2} & I_{2} & G_{2} & E_{2}
\end{array}\right]=\left[\begin{array}{l}
Y_{1} \\
Y_{2}
\end{array}\right] \\
& A_{i j}=\frac{z_{i j}}{x_{j}}
\end{aligned}
$$

Which is often called the input-output coefficients, or direct input coefficients. These coefficients can be interpreted as the number of input sector $i$ required to produce one unit of output of sector $j$. If there are $n$ sectors in the economy, there will be as many as the $n$ $x n$ coefficient $a_{i j}$. All coefficients can be expressed in a matrix, $A$, in the form of:

$$
A=\left[\begin{array}{llll}
a_{11} & a_{12} & \cdots & a_{1 n} \\
a_{21} & a_{22} & \cdots & \cdot \\
\cdots & \cdots & \cdots & \cdot \\
\cdots & \cdots & \cdots & \cdot \\
a_{n 1} & a_{n 2} & & a_{m n}
\end{array}\right]
$$

A matrix is often called the technology matrix. A matrix of each column shows the composition of inputs in the production process of the sector $i$, which reflects the technology used by the production sectors. 
Algebraic manipulation of condition above yields:

$$
Z_{i j}=a_{i j} X_{j}
$$

This equation confirms again that all the coefficients $a_{i j}$ other not reflect the relationship between the output and the input of sector $j$ to $i$ sector. In the analysis of the input-output relationship means the amount of the fixed nature of this relationship has not changed despite improvements in the economy. After getting the technology coefficients $a_{i j}$, then the system of equations can be written as follows:

$$
\begin{aligned}
& X_{1}=a_{11} X_{1}+a_{12} X_{2}+\cdots+a_{1 n} X_{n}+Y_{1} \\
& X_{2}=a_{11} X_{1}+a_{12} X_{2}+\cdots+a_{2 n} X_{n}+Y_{2} \\
& \vdots \\
& X_{n}=a_{n 1} X_{1}+a_{n 2} X_{2}+\cdots+a_{n n} X_{n}+Y_{2}
\end{aligned}
$$

By shifting all elements to the left, except $Y_{i}$, obtained from:

$X_{i}$ can be simplified into:

$$
\begin{aligned}
& \left(1-a_{11}\right) X_{1}-a_{12} X_{2}-\cdots a_{1 n} X_{n}=Y_{1} \\
& -A_{21} X_{1}-\left(1-a_{22}\right) X_{2}-\cdots a_{2 n} X_{n}=Y_{2} \\
& \vdots \\
& -A_{n 1} X_{1}-\left(1-a_{n 2}\right) X_{2}-\cdots a_{n n} X_{n}=Y_{2} \\
& (I-A) X=Y
\end{aligned}
$$

Where $I$, is the identity matrix of size $\mathrm{n} n x n$ matrix $A$ is as defined in advance, while $X$ and $Y$ is the column vector of the form:

$$
X=\left[\begin{array}{c}
X_{1} \\
X_{2} \\
\vdots \\
X_{n}
\end{array}\right]<-\rightarrow \text { and }<-\rightarrow X=\left[\begin{array}{c}
X_{1} \\
X_{2} \\
\vdots \\
X_{n}
\end{array}\right]
$$

If there is a change in final demand, then there will be changes in the pattern of national income. It can be written that: 


\section{Engineering Analysis and Projection I-O Table in 2005 and 2010}

To get I-O table in particular year (eg 1 year ), on the basis of the previous year I-O table ( ie year 0 ) is to produce a table of IO technology matrix is based on the technology matrix 0 I-O years, used RAS method. This method does not require a detailed survey to get the technology matrix, so it is appropriate to use I-O tables to predict the future by combining RAS method with projection models developed previously.

To explain the use of the method in obtaining the future of I-O RAS Table, a survey conducted in this method is replaced by the projection, which is done partially to obtain information from the three vectors. First, the column vector which is the sum of each row of the matrix $Z$ in the usual 1 denoted by $U$ (1). Second, the line vector is the sum of each column of the matrix $\mathrm{Z}$ in the usual 1 denoted by $\mathrm{V}$ (1). Third, of course, is the matrix $\mathrm{X}$ (number of output) in the first year, which is denoted by $\mathrm{X}$ (1).

In principle, the method seeks to obtain a matrix RAS technology in period 1 , which is denoted by A (1). There are two methods that can be used to predict the technology matrix A (1) on the assumption that stable matrix technology or not all the time. If stable, then A $(0)=\mathrm{A}(1)$, whereas if the technology matrix is not stable, then $\mathrm{A}(0) \neq \mathrm{A}(1)$.

The following describes the procedure with the RAS method using three economic sectors of production, assuming that $\mathrm{A}$ is unstable. This economy has data transactions between economic actors for years 0 to note also that the technology matrix:

$$
\begin{aligned}
& A(1)=\left[\begin{array}{lll}
a_{11}(1) & a_{12}(1) & a_{13}(1) \\
a_{21}(1) & a_{22}(1) & a_{23}(1) \\
a_{31}(1) & a_{32}(1) & a_{33}(1)
\end{array}\right] \\
& A(1)=\left[\begin{array}{lll}
a_{11}(0) & a_{12}(0) & a_{13}(0) \\
a_{21}(0) & a_{22}(0) & a_{23}(0) \\
a_{31}(0) & a_{32}(0) & a_{33}(0)
\end{array}\right]
\end{aligned}
$$

In the year 1 (one) believed that the technology matrix has changed because of the change of the technology used by the interconnected economy. But, new technology to create a matrix based on a survey of its own is not easy, so it was decided to use the RAS method. To run the RAS method needs some information about the economy in year 1. Results of data collection resulted in the following matrices: 


$$
X_{1}(1)=\left[\begin{array}{c}
X_{1}(1) \\
X_{1}(1) \\
X_{1}(1)
\end{array}\right] \leftrightarrow\left[\begin{array}{c}
U_{1}(1) \\
U_{1}(1) \\
U_{1}(1)
\end{array}\right] \leftrightarrow V(1)=\left[V_{1}(1) V_{2}(1) V_{3}(1)\right]
$$

Matrix technology owned pliers are stable over time which tells us that the period 0 technology matrixes with the exact same technology in period 1. Furthermore, it can be concluded that: $\mathrm{A}(0)=\mathrm{A}(1)$, Where the transaction matrix can be calculated in period 1 :

\section{Nuclear Reactor Power System}

\section{Table 4.}

\section{Cost Risk}

\begin{tabular}{|c|c|c|c|c|}
\hline & Development & Construction & Operation & Decommissioning \\
\hline 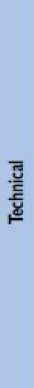 & $\begin{array}{l}\text { Regulatory assessment } \\
\text { Site suitability } \\
\text { Environmental impact } \\
\text { Planning approvals }\end{array}$ & $\begin{array}{l}\text { Safety } \\
\text { Design completion / } \\
\text { changes } \\
\text { Regulatory assessment / } \\
\text { approvals } \\
\text { Vendor and Contractor } \\
\text { performance } \\
\text { Equipment supply chain } \\
\text { Skilled and experienced } \\
\text { workforce } \\
\text { Construction quality } \\
\text { Transport routes to site } \\
\text { Industrial relations } \\
\text { Plant performance }\end{array}$ & $\begin{array}{l}\text { Safety } \\
\text { Plant performance } \\
\text { Skilled and } \\
\text { experienced } \\
\text { workforce } \\
\text { Nuclear event } \\
\text { elsewhere } \\
\text { Nuclear event } \\
\text { The environment } \\
\text { Fuel supply chain }\end{array}$ & $\begin{array}{l}\text { Safety } \\
\text { Design completion / } \\
\text { changes } \\
\text { Regulatory assessment } \\
\text { / approvals } \\
\text { Contractor } \\
\text { performance } \\
\text { Equipment supply } \\
\text { chain } \\
\text { Skilled and } \\
\text { experienced } \\
\text { workforce } \\
\text { Transport routes to/ } \\
\text { from site }\end{array}$ \\
\hline 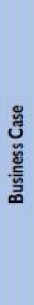 & $\begin{array}{l}\text { Economics } \\
\text { Demand forecast } \\
\text { Used fuel and } \\
\text { radioactive waste } \\
\text { disposal }\end{array}$ & $\begin{array}{l}\text { Design changes } \\
\text { Delay }\end{array}$ & $\begin{array}{l}\text { Electricity trading } \\
\text { arrangements } \\
\text { Electricity price } \\
\text { Carbon price } \\
\text { Fuel costs } \\
\text { Capital additions } \\
\text { Early closure } \\
\text { Cost of waste and } \\
\text { used fuel disposal } \\
\text { Decommissioning } \\
\text { fund performance }\end{array}$ & Decommissioning fund \\
\hline 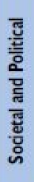 & \multicolumn{4}{|c|}{$\begin{array}{l}\text { General public support and local approval } \\
\text { Policy supporting the need for nuclear power } \\
\text { Policy for waste management } \\
\text { Decommissioning \& waste management mecha } \\
\text { Carbon pricing mechanism } \\
\text { Environmental policy }\end{array}$} \\
\hline
\end{tabular}

Technical considerations for efficient operational management: Safety margins, design margins, operational margins, security considerations, unit availability considerations, operating experience, materials assessment, maintenance and refueling considerations. 
However, Systems and topics for review included: NSSS, BOP, I\&C Systems, Electrical Systems, Civil, security and fire protection, operational consideration, and maintenance and refueling considerations, see OECD (2012).

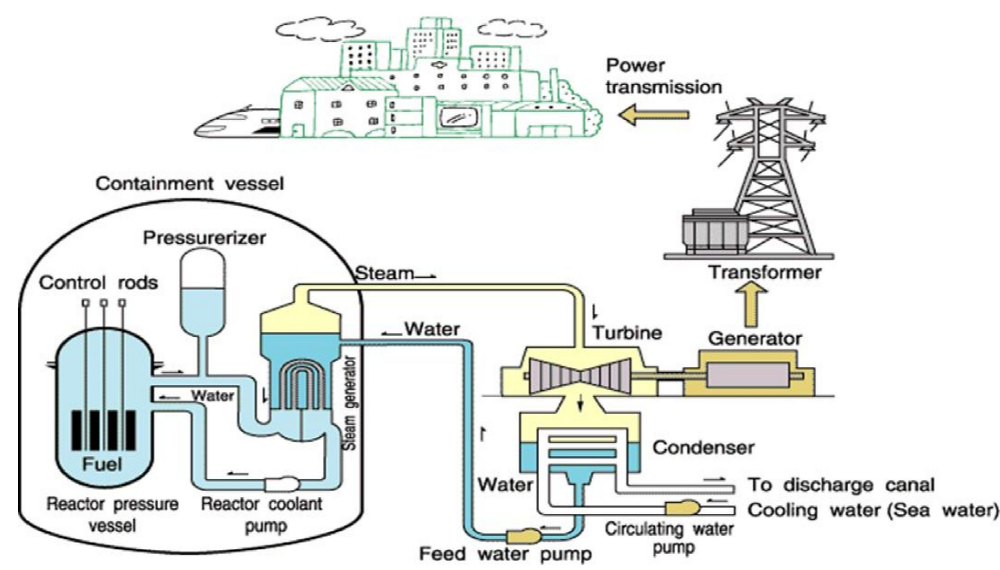

Source: KHNP, 2003- updated, Anonim (2010)

\section{Figure 5.}

PWR

The figure below, in figure 5 and figure 6 containing the different type of nuclear reactor type. Particularly in water cooling system, though the end of purpose is to create power transmission.

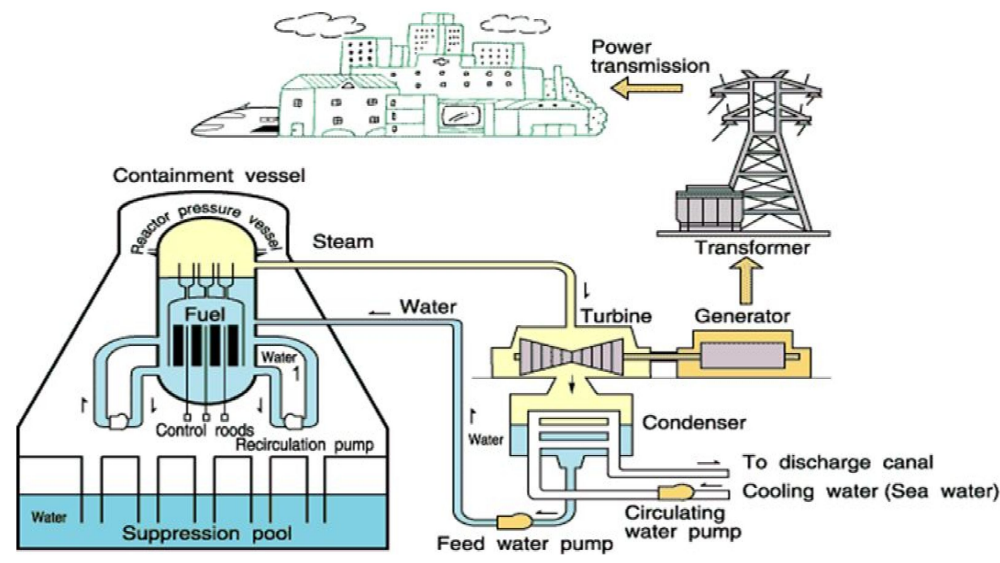

Source: KHNP, 2003- updated, Anonim (2010)

Figure 6.

BWR 
Component data base identification on KSNP - 1000 based on BOP, (balance of plant) and construction phase based on South Korea's experienced.

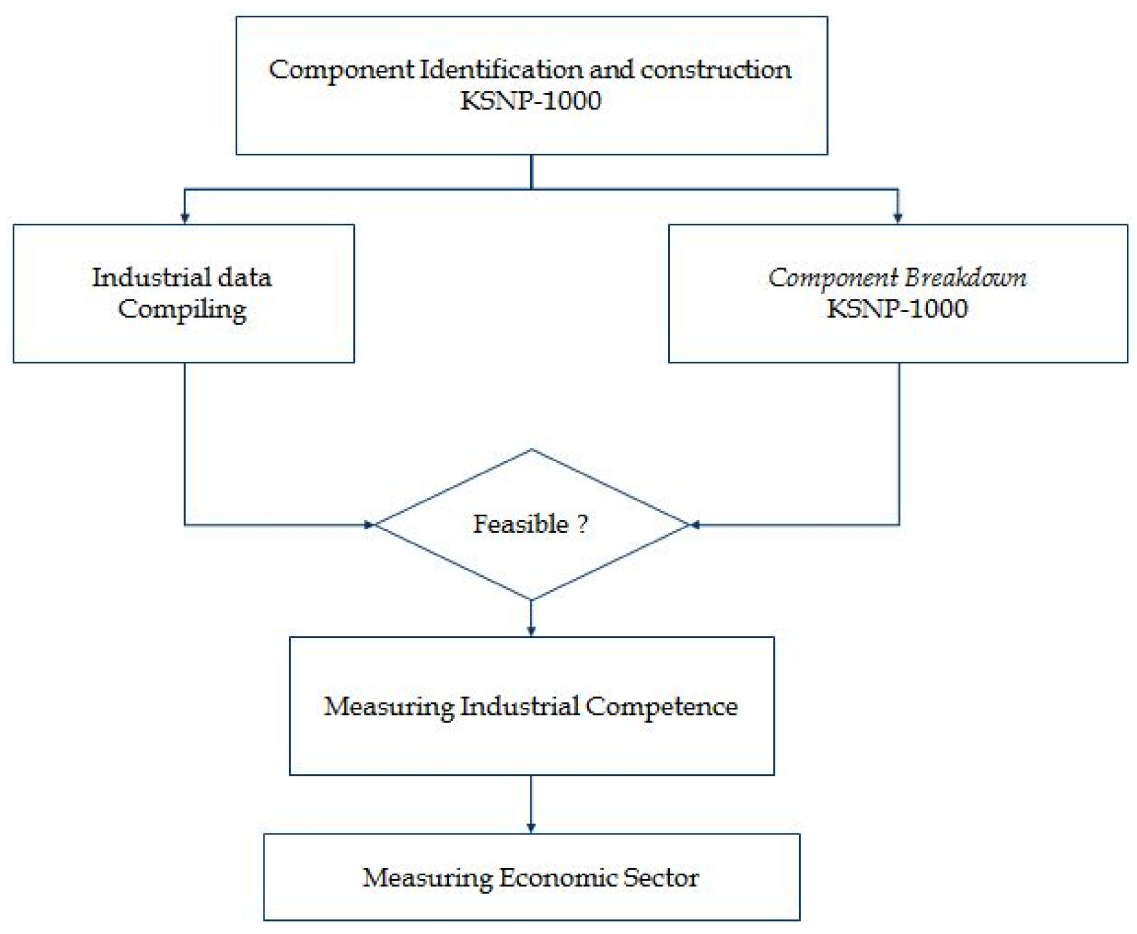

Source : KHNP and GMU-Data Base- updated

Figure 7.

The Flowchart Component Cost Identification and Construction Cost

\section{Indonesia's Nuclear Power Plants Location.}

The component analysis of nuclear power plant on KSNP type; the type of reactors needs all special building purpose for radioactive and nuclear safety. There are non-nuclear island; building, turbines, building system for electricity installation, computer network and control system, electricity transmission, diesel platform, etc.

Type of KNSP in 2004:

1. Nuclear Steam Supply System (NSSS)

2. Turbine and Generator $(\mathrm{T} / \mathrm{G})$ 
3. Fuel

4. Balance of plant (BOP) only, which permitted by KSNP CO., Ltd (KHNP), particularly for output product from stakeholder. There are in small number that will produce in local industries NSSS and T/G.

BOP, balance of plant for nuclear power plants:

1. Architecture

2. Building Construction

3. Electric and Electronic

4. Environmental aspects

5. Control and Instrumentals

6. Mechanic

7. Nuclear

8. Pipe

\section{Nuclear Power Plants Construction Phase}

The first construction phase through entire of finishing nuclear power plant is need global supply chain both local and international level. Industrial supporting system will survey to get feasible impact of nuclear power plants construction.

During nuclear power plants construction will absorb 4000 people both in international and domestic people. The first construction cost will take $10 \%$ from total cost of nuclear power plants construction. The positive impact is local people will get the job from road construction and nuclear power plants prep-construction.

Operational system of nuclear power plants construction should be well connected to regional economy. The negative impacts from plants construction have to remove, safely. Moreover, it can promote local economy, significantly.

All component analysis and nuclear power plant construction based on local industrial linked with construction plant needs. The tracing studies have found 63 industrial profiles that can promote the project. However, it will be first stage for local industry to be more efficient and high level of productivity to support sustainability of nuclear power plants construction.

The BOP (Balance of plant components) price has been determined in input output analysis and identify the necessities for power plants construction. Identification for local industries which can lead for produce plants equipment with high quality. The good and all services can be trace form I-O tables. From I-O table can be identified the price and goods 
based on economic sector activities.

The same methodology can be used for each power plants construction based on KSNP type to know how much it will take cost for each year plants construction. Mapping all cost can be done on I-O tables.

\section{The Input Demand for Construction}

Component analysis and break down cost have been identified for demand and domestic output within linked industries. All prices and all values of product using 2004 data to predict all construction phase between 2005- 2016, inflation rate has been implied in this studies. The inflation rate is the policy target from the government. The inflation rate is $7 \%$ (RP 10.000/US \$ 1). The pessimistic scenario inflation rate $4 \%$ with exchange rate RP $9.000 /$ US \$ 1).

\section{The Estimation Value Based on Final Demand in the End of Pproject:}

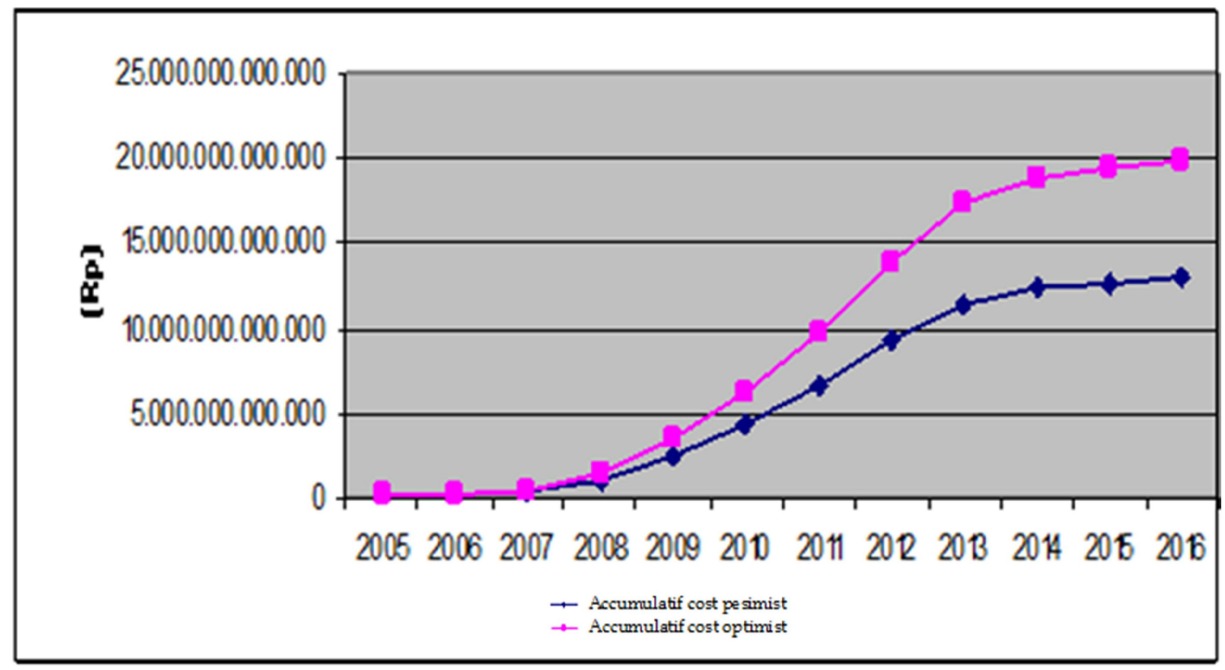

Source: GMU-Data Base- updated

Figure 8.

Accumulation Cost on Nuclear Power Plant Cost: S - Curve. 


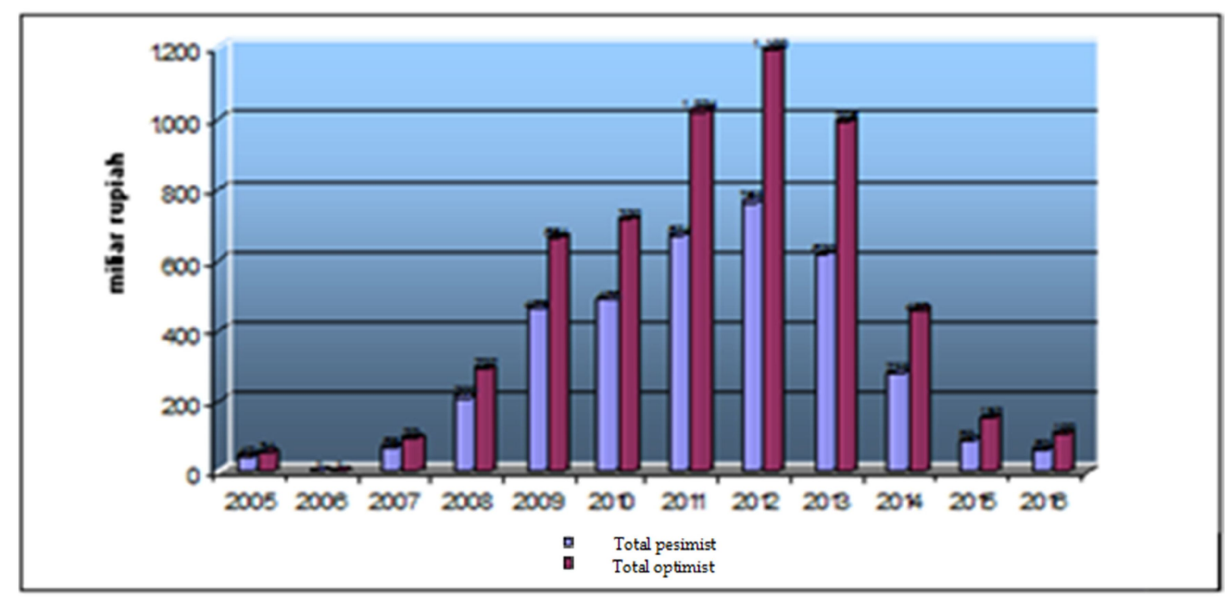

Source : GMU-Data Base- updated

\section{Figure 9.}

Income Effect 2005-2016

The increasing of economic sector activity will increase household production factors. It's shown that household income dispersion happened during preparation and construction execution, 2005-2016, ceteris paribus.

By the assumption of employment growth $1.57 \%$ per year, it can be calculated the additional job creation on existing nuclear power plants. It caused direct and indirect impact within nuclear power plants construction.

All scenarios are based on assumption, ceteris paribus. The labor growth $1.57 \%$ per year calculated as additional labor force due to nuclear power plant construction. The job creation simulation was 475.197 people will get job place, particularly for certain industrial sectors.

If using the pessimist scenario (Inflation rate $4 \%$, exchange rate RP 9.000/US \$1), total labor force impacts during construction 2005-2016, 475.197 people. Then, with optimistic scenario, (inflation rate 7\%, exchange rate RP. 10,000/US \$1), will give impact to labor force 735.909 people.

\section{Conclusion}

During construction 2010-2016 the economy of central Java has been increasing from $0.53 \%$ at $2010,0.54 \%$ at 2011 .

For local economy, Jepara's resident during construction phase economic growth 
around $0.75 \%$ predicted happened in 2005 and $2.46 \%$ in 2009 . The economic growth for central Java predicted $3.13 \%$ in 2010 and $3.18 \%$ in 2010 .

The analysis of component and cost-break down structure shows the ability of Domestics Company to supply part of components in nuclear power plants construction at Peninsula of Muria. The construction cost $25 \%$ coming from domestic input. The pattern of construction planning is follows S-curve. It can be stated here that a small amount of cost at the first phase, then increasing in the second phase, finally decreasing at final construction. However, the calculation of dismantling is excluded, due to focused on company and consultant views. The dismantling views will deliver by local-national government and work together with NGO. The company and consultant said that the benefit is greater than dismantling cost, significantly.

The positive impact is 1). The national output will increase around 14 billion euros by using 1 euro = Rp.14, 000, 2). Increasing revenue from the owner of production factors 2.4 billion euros, 1 euro = Rp.14, 000 and for the job creation will absorb 735.909 people

However, in pessimist scenario shows that nuclear power plants will gave impact on national output but less than optimist scenario. The pessimist scenarios absorb labor force 475,197 people. The optimist scenario will give higher impact to national output 2, 2 billion euros, and then the increasing income of the owner of production factor 3, 6 billion euros. The most significant to attract labor force is construction sector, cement industry, transportation, mining, mineral industry, bamboo, wood, rattan, metal and other metal products. 


\section{References}

Anonim. (2004) NSSS System on KSNP, KHNP, Korea (Tech. Rep.). KHNP.

Anonim. (2010) the Future of Nuclear Power. An interdisciplinary MIT Study.

Berkeley, A. R., \& Wallace, M. (2010) A Framework for Establishing Critical Infrastructure Resilience Goals (T. Council, Ed.).

CBS, J. (1998) Tabel Input-Output Indonesia 1995, (B. P. Statistik, Ed.).

Foulkes, T. (2010) Nuclear lessons learned (Tech. Rep.). The Royal Academy of Engineering.

Hunt, P. (2012) The Future of Nuclear Energy in the UK (Tech. Rep.). Birmingham Policy Commission.

IAEA. (1975) Steps to Nuclear Power: A Guidebook (I. Vienna, Ed.). IAEA Vienna.

IAEA. (2013) Nuclear Reactor Technology Assessment for Near Term Deployment (Tech. Rep.)

OECD. (2012) Nuclear Education and Training: From Concern to Capability (Tech. Rep.).

Sulfikar, A. (2010) Nuclear Revival in Post-Suharto, Indonesia.

Asian Survey, No 2, ISSN 0004-4687, Electronic ISSN 1533-838X, Vol. 50, 265-286.

Yount, L. (2005) Energy Supply. Facts on File, Inc. 